\title{
Bio-efficacy of Different Insecticides against Mealy Bug Infesting Custard Apple
}

\author{
A. H. Barad", M. V. Dabhi, N. K. Rathod and H. N. Prajapati \\ Department of Plant Protection, College of Horticulture, Anand Agricultural University, \\ Anand-388110, Gujarat, India \\ *Corresponding author
}

\begin{tabular}{|c|c|}
\hline & A B S T R A C T \\
\hline & \multirow{4}{*}{$\begin{array}{l}\text { The experiment was conducted for the year } 2015 \text { and } 2016 \text { to evaluate five } \\
\text { different insecticides against mealy bug infesting custard apple by } \\
\text { Department of Plant protection, College of Horticulture, Anand } \\
\text { Agricultural University, Anand in completely randomize design at two } \\
\text { farmers field at Keliavasana and Chiloda villages. Among the five } \\
\text { insecticides, two sprays of profenophos } 50 \text { EC } 0.05 \text { per cent @ } 10 \mathrm{ml} / 10 \text { lit } \\
\text { of water proved effective in the management of mealy bug in custard apple. } \\
\text { The residue analysis of fruits treated with two application profenophos } 50 \\
\text { EC } 0.05 \text { per cent showed residue level below detectable level after } 15 \text { days } \\
\text { of second application. }\end{array}$} \\
\hline $\begin{array}{l}\text { Custard apple, } \\
\text { Ferrisiavirgata, } \\
\text { Profenophos } 50 \text { EC }\end{array}$ & \\
\hline Article Info & \\
\hline $\begin{array}{l}\text { Accepted: } \\
\text { 15 August } 2020 \\
\text { Available Online: } \\
\text { 10 September } 2020\end{array}$ & \\
\hline
\end{tabular}

\section{Introduction}

The custard apple (Annona squamosa Linneus, Family: Annonaceae), native of South America, is very hardy tropical fruit crop, tolerant to drought, salinity and saline irrigation water to certain extent. The production of custard apple at the farmer's field is quite low due to various reasons. Among the several factors responsible for low yield and quality, insect pest is one of the most important limiting factors. More than 20 species of insect pests have been reported damaging to custard apple plants in India (Ayyar, 1938; Shukla and Tandon, 1984;
Babu and Azam, 1987). Three species of mealy bug namely Planococcus citri Risso, Maconellicoccus hirsutus (Green) and Ferrisiavirgata (Cockerel) have been recorded on custard apple. These species were reported causing the most severe damage by sucking the cell sap from fruits, leaves and young shoots (Mani and Krishnamoorthy, 1989). With view to this present experiment was planned with an objective to evaluate bioefficacy of different insecticides against mealy bug infesting custard apple as well as to study the residue aspect of the effective insecticide. 


\section{Materials and Methods}

The experiment was carried out in completely randomize design with five insecticidal treatments and a control (Table 1) with a custard apple variety Sindhan for the years 2015 and 2016 at farmer's fields in one at Keliya Vasna and Chaloda village of Dholka taluka Gujarat, India. Two applications of insecticides had been given. A sticker $10 \mathrm{ml}$ was added in 10 liters, of all insecticidal solution for both sprays. First application was done at the initiation of the pest and second spray was applied after 15 days of first spray.
For recording observations, ten fruits were selected randomly and the observations on nymphs and adult's population of mealy bugs were recorded from randomly selected fruits at one day before and 3,7 and 10 days after each spray. The species of mealy bug was Ferrisia virgata (Cockerell) identified at IARI, New Delhi wide letter No. BRS no. 2812-28-16/13D. The residue study of the effective insecticide was also carried out as per standard method at Pesticide Research Laboratory, ICAR, Unit 9, Anand Agricultural University, Anand.

\section{Treatment detail}

\begin{tabular}{|c|c|}
\hline Treat. No. & Name of insecticides and dose \\
\hline $\mathbf{T}_{1}$ & Profenophos 50 EC @ 0.05\% / 10 ml/ 10 lit of water (400 g.a.i/ha) \\
\hline $\mathbf{T}_{2}$ & Indoxacarb 15.8 EC @ $0.0079 \% / 5$ ml/ 10 lit of water (63.2 g.a.i/ha) \\
\hline $\mathbf{T}_{3}$ & Buprofezin 25 SC @ 0.05\% / 20 ml/ 10 lit of water (400 g.a.i/ha) \\
\hline $\mathbf{T}_{4}$ & Chlorpyriphos 20 EC @ 0.04\% / 20 ml/ 10 lit of water (320 g.a.i/ha) \\
\hline $\mathbf{T}_{5}$ & Cypermethrin10 EC @ 0.01\% / 10 ml/ 10 lit of water (80 g.a.i $/$ ha) \\
\hline$T^{6}$ & Control (water spray) \\
\hline
\end{tabular}

\section{Results and Discussion}

\section{Location Keliavasana}

The pooled data presented in Table 1 revealed that all the insecticidal treatments were significantly superior over the control in both the year, location and pooled. The results of the year 2015 (Table 1), for pooled over period over sprays reveled that profenophos 0.05 per cent recorded significant lower mealybug population (24.20 nymphs and adult females/fruit) than rest of the treatments and it was at par with buprofezin 0.05 per cent (25.00 nymphs and adult females/fruit) and indoxacarb 0.0079 per cent $(25.30$ nymphs and adult females/fruit).

For the year 2016 (Table 1) the data on pooled over period reveled that profenophos 0.05 per cent recorded significant lower mealy bug population (14.21 nymphs and adult females/fruit) than rest of the treatments. The treatments of buprofezin 0.05 per cent (19.62 nymphs and adult females/fruit) and indoxacarb 0.0079 per cent (19.9 nymphs and adult females/fruit) remained at par with each other and next effective in controlling the pest.

\section{Location Chiloda}

The data of the year 2015 of pooled over period and spray on mealy bug population reveled that profenophos 0.05 per cent recorded significantly superior in recording minimum population (25.60 nymphs and adult females/fruit) than the rest of treatments and statistically it was at par with all the insecticidal treatments (Table 1). The data on pooled over period and sprays reveled that profenophos 0.05 percent recorded 
Table.2 Residual analysis

\begin{tabular}{|c|c|c|c|c|c|c|c|c|c|c|}
\hline \multirow[t]{2}{*}{ Year } & \multirow[t]{2}{*}{ Crop } & \multirow[t]{2}{*}{ Pest } & \multirow{2}{*}{$\begin{array}{c}\text { Pesticides } \\
\text { with } \\
\text { formulation }\end{array}$} & \multicolumn{4}{|c|}{ Dosage } & \multirow{2}{*}{$\begin{array}{l}\text { Application } \\
\text { schedule }\end{array}$} & \multirow{2}{*}{$\begin{array}{c}\text { Residual } \\
\text { analysis }\end{array}$} & \multirow{2}{*}{$\begin{array}{c}\text { Limit of } \\
\text { Quantitation } \\
\text { (LOQ) }\end{array}$} \\
\hline & & & & $\underset{\mathrm{a} . \mathrm{i} / \mathrm{ha}}{\mathrm{g}}$ & $\begin{array}{c}\text { Quantity of } \\
\text { formulation } \\
\text { per ha }\end{array}$ & $\begin{array}{l}\text { Conc. } \\
(\%)\end{array}$ & $\begin{array}{c}\text { Dilution } \\
\text { in water } \\
\text { (10 lit.) }\end{array}$ & & & \\
\hline 2016 & $\begin{array}{l}\text { Custard } \\
\text { apple }\end{array}$ & $\begin{array}{l}\text { Mealy } \\
\text { bug }\end{array}$ & $\begin{array}{c}\text { Profenophos } \\
50 \% \text { EC }\end{array}$ & 400 & $800 \mathrm{ml}$ & 0.05 & $1 \mathrm{ml}$ & $\begin{array}{c}\text { Initiation of } \\
\text { pest } \\
15 \text { days of } \\
\text { first spray }\end{array}$ & BDL & 0.05 \\
\hline
\end{tabular}

BDL: Below determent level 0.05 ppm

Fig.1 Untreated tree $T_{1}$ treated tree

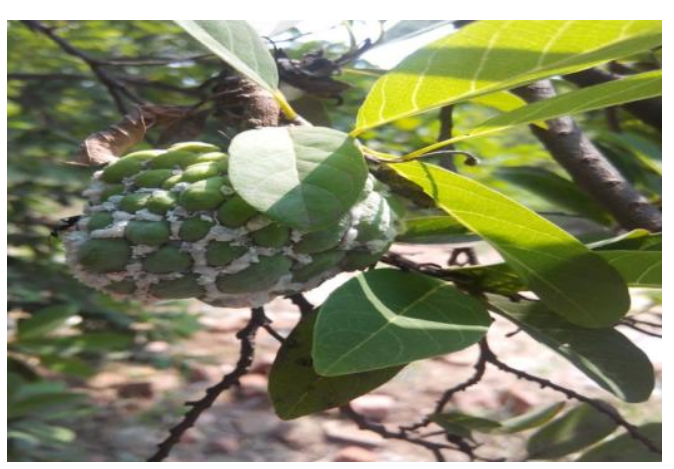

The results of pooled over periods and years indicated (Table 1) that profenophos 0.05 per cent recorded significant lower mealy bug population (18.83 nymphs and adult females/ fruit) than rest of the treatments. The treatments of indoxacarb 0.0079 per cent and buprofezin 0.05 per cent remained statistically at par with each other and next effective in controlling the pest.

Muthukrishnan et al., (2005), revealed that buprofezin 25 SC @ $1125 \mathrm{ml} / \mathrm{ha}$ sprayed thrice at 15 days interval reduced the congregation of $M$. hirsustus on grape and increased the yield. Balikai (2005), reported that buprofezin $25 \mathrm{SC} @ 1125 \mathrm{ml} / \mathrm{ha}$, along with fish oil rosin soap (meenark) at $3125 \mathrm{~g}$ /ha was effective for the management of the grape vine mealybug. Bhosle et al., (2009) reported that the yield of seed cotton was significantly highest in acephate $70 \mathrm{SP}$ and profenophos $50 \mathrm{EC}$.

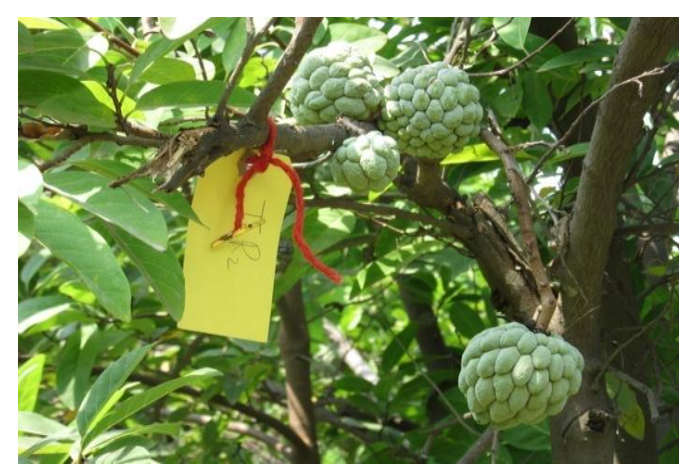

The lowest larval population and highest reduction of $M$. hirsutus was recorded by Naik et al., (2017) on custard apple, through profenophos $(0.05 \%)$ and methyl parathion $(0.05 \%)$. More or less similar results were also achieved in this experiment.

Insecticidal residue analysis was carried out for custard apple fruits after 15 days of last application of profenophos 50 EC @ $0.05 \%$ at Pesticide Research Laboratory, ICAR, Unit 9, Anand Agricultural University, Anand suggested that it was below detectable level (Table 2).

In a conclusion, two sprays of profenophos $50 \%$ EC 0.05 per cent @ $10 \mathrm{ml} / 10$ lit of water, starting from appearance of the pest and second spray was done at 15 days of first spray proved effective in the management of mealybug in custard apple in field conditions. The analysis of the fruits treated with profenophos 50 EC @ $0.05 \%$ after 15 days of 
second spray application revealed that the residue level was below detectable level.

\section{References}

Ayyar, T.V.R. (1938). An annotated conspectus of insects affecting fruit crops in S. India. Madras Agric. J., 26 (9): 341-351

Babu, T. R. and Azam, K. M. (1987). Studies on biology, host spectrum and seasonal population fluctuation of the mealy bug, Maconellicoccus hirsutus (Green) on grapevine. Indian Journal of Horticulture, 44(3-4): 284-288.

Balikai, R. A (2005). Management of grape mealybug, Maconellicoccus hirsutus (Green) using insect growth regulator. Research on Crops.; 6 (1):68-71.

Bhosle, B. B, Sharma O. P, More DG, Bhede B. V, Bambawale O. M (2009). Management of mealybug, Phenacoccus solenopsis Tinsley in rainfed cotton, Gossypium hirsutum.
Indian journal of Agriculture Science. 79 (3):199-202.

Mani, M. and Krishnamoorthy, A. (1989). Occurrence of mealybug and their natural enemies on custard apple around Bangalore, South India. J. Biol. Contl., 3 (1): 77.

Muthukrishnan, N, Manohan T, Thirumalai T, Anbu S. (2005). Evaluation of buprofezin for the management of grape mealybug, Maconellicoccus hirsutus (green). Journal of Entomological Research.; 29 (4): 339-344.

NaikS H; Jagadeesh, K S and Basavaraju B. S (2017). Biology and management of pink mealy bug, Maconellicoccus hirsutus (Green) on custard apple (Anonna squamosa L.). Journal of Entomology and Zoology Studies5 (5): 1014-1018.

Shukla, R.P. and Tandon, P.L. (1984). Indiainsect pests on custard apple. Plant Protection Bulletin, 32(1): 31.

\section{How to cite this article:}

Barad, A. H., M. V. Dabhi, N. K. Rathod and Prajapati, H. N. 2020. Bio-efficacy of Different Insecticides against Mealy Bug Infesting Custard Apple. Int.J.Curr.Microbiol.App.Sci. 9(09): 1723-1727. doi: https://doi.org/10.20546/ijcmas.2020.909.213 